\author{
R.L. Politanskyi ${ }^{1}$, Z.M. Nytrebych ${ }^{2}$, R.I. Petryshyn ${ }^{1}$, I.T. Kogut ${ }^{3}$, \\ O.M. Malanchuk ${ }^{4}$, M.V. Vistak ${ }^{4}$
}

\title{
Simulation of the Propagation of Electromagnetic Oscillations by the Method of the Modified Equation of the Telegraph Line
}

\author{
${ }^{1}$ Yuriy Fedkovych Chernivtsi National University, Chernivtsi,Ukraine, r.politansky@chnu.edu.ua \\ ${ }^{2}$ Lviv Polytechnic National University, Lviv, Ukraine, znytrebych@gmail.com \\ ${ }^{3}$ Vasyl Stefanyk Precarpathian National University, Ivano-Frankivsk, Ukraine, igorkohut2202@gmail.com \\ ${ }^{4}$ Danylo Halytsky Lviv National Medical University, Lviv, Ukraine, oksana.malan@gmail.com
}

\begin{abstract}
The physical processes associated with the propagation of electromagnetic oscillations in a long line, the size of which is the same or slightly greater than the length of the electromagnetic wave (not more than ten times) are considered in the work. As a research method, the differential-symbol method, which is applied to the modified equation of the telegraph line is used. The two-point conditions for the problem as well as additional parameters that are coefficients of the first derivatives in terms of coordinate and time in comparison with the classical equation of the telegraph line are considered as parameters for controlling the process of propagation of electromagnetic oscillations. Based on the differential-symbol method, the two-point in time conditions under which the most characteristic oscillatory processes are realized in a long line is found. Based on the research, it is possible to draw conclusions about the effectiveness of analytical methods for the analysis of specific technical objects and control of the processes that take place in them.
\end{abstract}

Keywords: telegraph line, two-point problem.

Received 5 February 2021; Accepted 10 March 2021.

\section{Introduction}

The development of telecommunication technologies has led to an active search for new information transmission technologies which use complex chaotic signals [1], methods of signal processing [2] and modulation using artificial intelligence systems [3]. The transition to new frequency bands and the complexity of signal processing processes led to the search for new models and methods in radio systems $[4,5]$.

Another example where accurate calculation of transients, phase and amplitude of oscillations in currentcarrying circuits is required are the primary devices of measuring systems. Thus, highly sensitive optical sensors are promising for qualitative and quantitative analysis of harmful substances, including biochemical substances [68]. The combination of numerical and analytical methods can increase the efficiency of calculations performed to model real systems [9] and their practical improvement. Computer simulation methods designed to calculate the characteristics of these devices and the precise selection of their parameters require accurate calculation of highfrequency processes occurring in signal circuits [10], and refined models of electromagnetic oscillation propagation can solve this problem.

One of the most studied problems of electrodynamics is the problem of propagation of electromagnetic oscillations in a long line [11, 12]. A long line is formed by two or more parallel insulated conductors, the distance between which is much smaller than their length. The equivalent electrical circuit of the long line is shown in Fig. 1.

The equivalent electrical scheme of a long line allows you to build a mathematical model called the telegraph equation $[13,14]$ : 


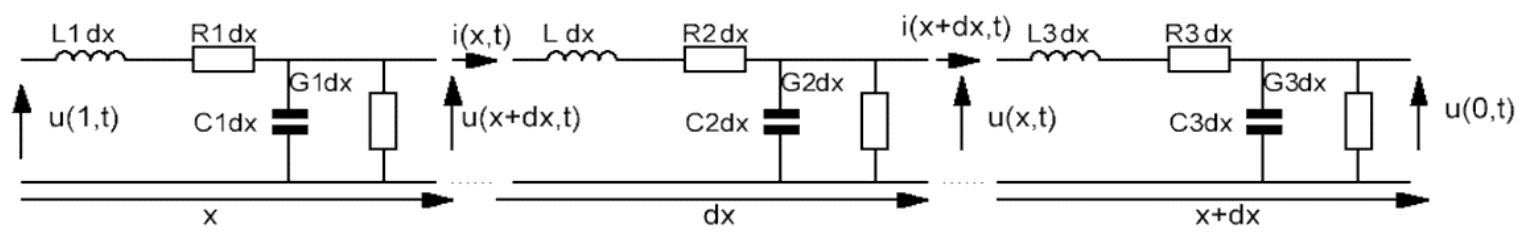

Fig. 1. Scheme of equivalent electric circuit of a long line.

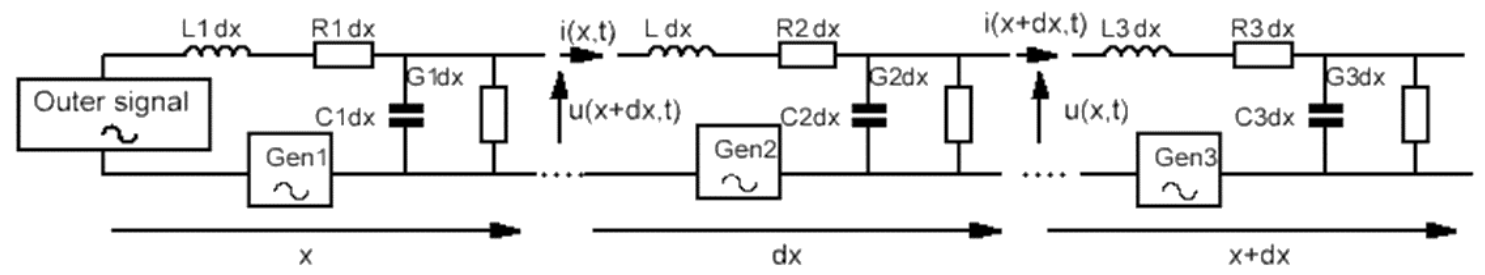

Fig. 2. Equivalent electrical circuit of the modified long line (with additional current and voltage sources).

$$
\left\{\begin{array}{l}
\frac{\partial u}{\partial x}=r i+l \frac{\partial i}{\partial t} \\
\frac{\partial i}{\partial x}=g u+c \frac{\partial u}{\partial t} .
\end{array}\right.
$$

In system (1), the unknown variables are the current $i(x, t)$ and voltage $u(x, t)$ in the line, which in the general case are functions of the coordinate $x$ and time $t$. In this equation, we assume that the line is homogeneous, and we replace all the point values of resistance, conductivity, inductance and capacitance by the distributed values reduced to the unit length of the circuit: $r$ - specific resistance, Ohm $/ \mathrm{m} ; g-$ specific conductivity, $\mathrm{S} / \mathrm{m} ; l-$ specific inductance, $\mathrm{H} / \mathrm{m} ; c-$ specific capacitance, $\mathrm{F} / \mathrm{m}$.

Using Ohm's law, we can derive from system (1) one equation of the second order with respect to one unknown function $u(x, t)[15,16]$ :

$$
\frac{\partial^{2} U}{\partial x^{2}}=\frac{1}{\alpha^{2}} \cdot \frac{\partial^{2} U}{\partial t^{2}}+D \cdot \frac{\partial U}{\partial t}+C \cdot U
$$

where $\alpha, D$, and $C$ are new parameters of the mathematical model. Let us turn to the physical content of these parameters, which are related to the electrophysical parameters of the system by the following relations:

$$
\alpha=\frac{1}{\sqrt{l c}} ; \quad D=l g+r c ; \quad C=r g .
$$

The parameter $\alpha$ is constant for the whole line and determines the frequency of current and voltage oscillations. The parameter $D$ plays the role of the attenuation of the amplitude of oscillations, which is associated with possible energy losses owing to active resistance along the line and the conductivity between the wires which form it. The parameter $\mathrm{C}$ affects the frequency characteristics of the system by changing the oscillation frequency, as we show in the next section.

The influence of the two-point in time conditions and the above-mentioned parameters in the found solutions is investigated in the work. These solutions are exponential decrease or increase in the amplitude of oscillations and decreasing oscillations.

A significant limitation of the classical model is that it does not provide a solution to the problem of the active line, which contains additional sources of current and / or voltage. However, the introduction of additional sources of currents and / or voltages can significantly change the wave process. In order to give this process the properties of the controlled, you need to know in advance all the possible types of waves that can be implemented. The equivalent electrical circuit of the modified homogeneous long line is shown in Fig. 2.

To model a homogeneous long line with external current and / or voltage sources, which we will hereinafter call an active long homogeneous line, we proposed a modified telegraph line equation in which the influence of external sources is modelled by adding the first derivatives in time and wave propagation coordinates.

The modified equation of the telegraph line has the following form:

$$
\frac{\partial^{2} U}{\partial x^{2}}=\frac{1}{\alpha^{2}} \frac{\partial^{2} U}{\partial t^{2}}+D \frac{\partial U}{\partial t}+B \frac{\partial U}{\partial x}+C U .
$$

Modification of this equation by introducing terms, which are the first derivatives in time and coordinate, makes it possible to increase the number of possible solutions of the equation, covering a wider range of processes. In practice, such a modification means a complication of the physical system.

\section{Calculation of processes in a long line with the superimposed conditions of a two-point problem}

\subsection{Physical parameters of the problem and their} physical meaning

Consider a long line by setting the values of linear 
inductance, capacitance, resistance and conductivity, which are characteristic of the propagation of highfrequency electromagnetic oscillations with frequency $f=3 \cdot 10^{8} \mathrm{~Hz}$, specific inductance: $l=0.2 \cdot 10^{-6} \mathrm{H} / \mathrm{m}$, specific capacity $c=2 \cdot 10^{-11} \mathrm{~F} / \mathrm{m}, \quad$ resistivity $r=3 \cdot 10^{-7} \mathrm{Ohm} / \mathrm{m}$ (aluminium), specific conductivity $g=10^{-3} \mathrm{~S} / \mathrm{m}$ (soil of medium humidity). Then the values of the coefficients $\alpha, D$, and $C$ determined by the selected electrophysical parameters: $\alpha=5 \cdot 10^{8} \mathrm{~s} / \mathrm{m}$ (the parameter which determines the oscillation frequency), $D=2 \cdot 10^{-10} \mathrm{~s} / \mathrm{m}^{2}$ (the parameter which determines the ability of the line to absorb electromagnetic energy due to leakage of conduction currents), $\mathrm{C}=3 \cdot 10^{-10} 1 / \mathrm{m}^{2}$ (the gain of the voltage gradient along the line, it is determined by the specific resistance $r$ and the conductivity $g$ in the line).

Next, we consider a two-point problem with time conditions of the Dirichlet type (4) for two types conditions, namely for a constant value and a periodic $x$ coordinate function:

$$
\left\{\begin{array}{l}
u(0, x)=\varphi_{1}(x) \\
u(l, x)=\varphi_{2}(x)
\end{array}\right.
$$

\subsection{A two-point problem with a constant voltage along a long line \\ Consider a two-point problem with two-point conditions in the form of a constant voltage applied along a line at the initial moment of time $t=0$ and at some other point in time $t=l$. Using the differential-symbol method [17-20], we can write a generalized solution of the two-point problem (3), (4) in the following form:}

$$
U(x, t)=-\frac{e^{-\frac{\alpha^{2} D t}{2}} \cdot\left[c_{1} \cdot \sinh \left(\alpha(t-l) / 2 \cdot \sqrt{(\alpha D)^{2}-4 C}\right)-c_{2} e^{\frac{\alpha^{2} D l}{2}} \cdot \sinh \left(\alpha t / 2 \cdot \sqrt{(\alpha D)^{2}-4 C}\right)\right]}{\sinh \left(\alpha l / 2 \cdot \sqrt{(\alpha D)^{2}-4 C}\right)} .
$$

Obviously, the nature of the wave process is determined by the sign of the root expression $(\alpha D)^{2}-4 C$, but for the selected parameter values the first term is much higher than the second, so the root expression will always have a positive value for oscillations of electromagnetic nature.

For further calculations we use the value of the time constant $l=10^{-6} c$, or 1 microsecond. The accuracy of determining this time is at least 0.1 microseconds, which is a realistic value for modern electronic devices. Next, using the approximate value of the root expression $(\alpha D)^{2}-4 C \approx(\alpha D)^{2}$ and an approximate value for the expression $\sinh \left(\alpha l / 2 \cdot \sqrt{(\alpha D)^{2}-4 C}\right) \approx e^{\frac{\alpha^{2} D l}{2}}$, we are writing the solution of the problem in a form convenient for analysis:

$$
U(x, t) \approx c_{2}+\left(c_{1}-c_{2}\right) \cdot e^{-\alpha^{2} D t} .
$$

Figure 3 shows the time dependences of the voltage in the line for two cases: a) voltage rise, b) voltage decline. The values of the two-point conditions for the case of growth are: $c_{1}=1 \mathrm{~V}, c_{2}=2 \mathrm{~V}$. In the case of a decline, the two-point conditions have the following values: $c_{1}=2 \mathrm{~V}, c_{2}=1 \mathrm{~V}$.

Thus, if the two-point conditions of a problem are constant voltage along a long line, then the system undergoes an exponential decrease or increase in voltage,

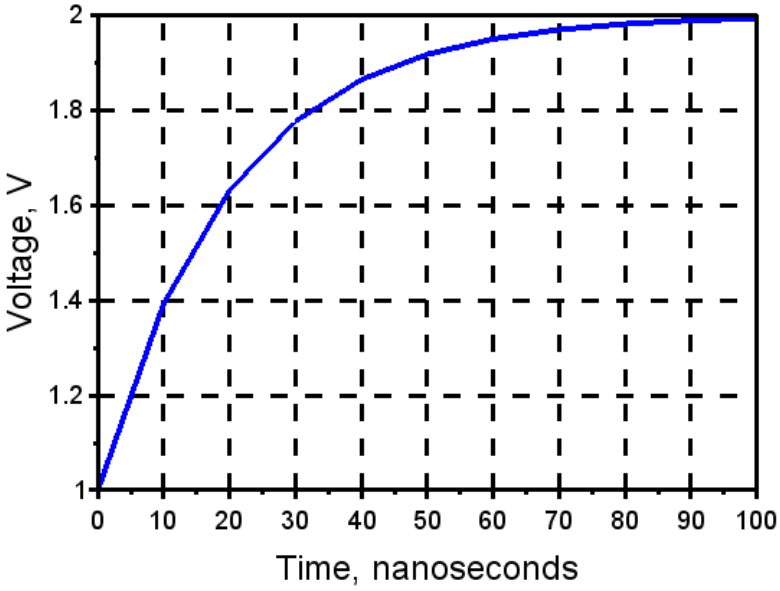

a)

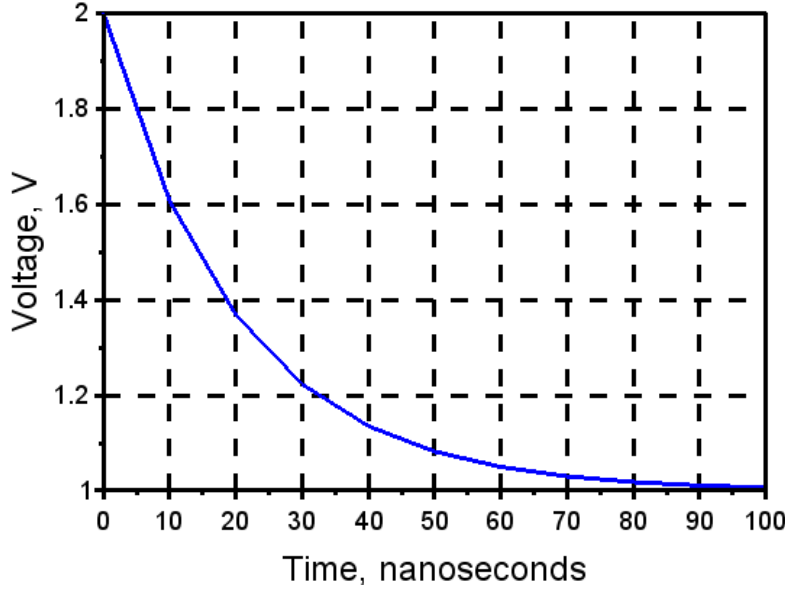

b)

Fig. 3. Time dependence of oscillation amplitude in a telegraph line for constant two-point conditions and constants corresponding to the process of electromagnetic wave propagation in a telegraph line:

a) voltage rise $\left.c_{1}=1 \mathrm{~V}, c_{2}=2 \mathrm{~V}, \mathrm{~b}\right)$ voltage drop $c_{1}=2 \mathrm{~V}, c_{2}=1 \mathrm{~V}$. 
depending on which of the voltage values is greater: at the initial or at some other point in time. The course of the process under such conditions does not depend on the $x$ coordinate, i.e. the voltage has the same values for the entire line at any time. The decrement is determined by the values of the parameters $\alpha$ and $D$, and its value is: $\chi=\alpha^{2} D=5 \cdot 10^{7} s^{-1}$.

\subsection{Conditions of a two-point problem in the} form of a periodic function on a spatial variable

Consider the case with periodic conditions of a twopoint problem, in which the voltage value at the initial moment $t=0$ and some other time $t=l$ are given as a periodic coordinate function. As a periodic condition, we use the simplest periodic function, namely the harmonic oscillation. Then the two-point conditions of the problem have the following form:

$$
\left\{\begin{array}{l}
U(0, x)=\varphi_{1}(x)=c_{1} \sin \left(n_{1} x\right) \\
U(l, x)=\varphi_{2}(x)=c_{2} \sin \left(n_{2} x\right)
\end{array}\right.
$$

where $n_{1}$ and $n_{2}$ are arbitrary real numbers.

The general solution for the factors $c_{1}$ i $c_{2}$ for the given conditions (7) of the two-point problem is determined by the fundamental solutions of the partial differential equation (3):

$$
\begin{gathered}
U(t, x)=\frac{1}{2 i}\left\{\left.c_{1} \cdot\left[\widehat{G}_{1}(t, \mu) e^{\mu x}\right]\right|_{\mu=i n_{1}}-\left.c_{1} \cdot\left[\widehat{G}_{1}(t, \mu) e^{\mu x}\right]\right|_{\mu=-i n_{1}}+\right. \\
\left.+\left.c_{2} \cdot\left[\widehat{G}_{2}(t, \mu) e^{\mu x}\right]\right|_{\mu=i n_{2}}-\left.c_{2} \cdot\left[\widehat{G}_{2}(t, \mu) e^{\mu x}\right]\right|_{\mu=-i n_{2}}\right\}
\end{gathered}
$$

where $\widehat{G}_{1}(t, \mu)=\frac{e^{-\frac{1}{2} \alpha^{2} D t} \cdot \sinh \left[\frac{1}{2} \alpha(l-t) \eta(\mu)\right]}{\sinh \left[\frac{1}{2} \alpha \eta(\mu)\right]}, \widehat{G}_{2}(t, \mu)=\frac{e^{-\frac{1}{2} \alpha^{2} D(t-l)} \cdot \sinh \left[\frac{1}{2} \alpha t \eta(\mu)\right]}{\sinh \left[\frac{1}{2} \alpha \eta(\mu)\right]}$.

We find the value of the function $\eta(\mu)$ for values $\mu= \pm i n_{1}, \pm i n_{2}$ :

$$
\begin{aligned}
& \eta\left( \pm i n_{1}\right)=\sqrt{(\alpha D)^{2}+4 \cdot\left(-n_{1}^{2} \mp i n_{1} B-C\right)}, \\
& \eta\left( \pm i n_{2}\right)=\sqrt{(\alpha D)^{2}+4 \cdot\left(-n_{2}^{2} \mp i n_{2} B-C\right)} .
\end{aligned}
$$

Let us find the solutions of the equation for $B=0$. Because the values of the constants $(\alpha D)^{2}=0.01$, $\mathrm{C}=3 \cdot 10^{-10}$, then $(\alpha D)^{2} \gg \mathrm{C}$, therefore value $\eta(\mu)$ can be considered approximately equal:

$$
\begin{aligned}
& \eta\left( \pm i n_{1}\right) \approx i \cdot 2 n_{1}, \\
& \eta\left( \pm i n_{2}\right) \approx i \cdot 2 n_{2} .
\end{aligned}
$$

We will write down separately all terms of expression (8):

$$
\begin{gathered}
{\left.\left[\widehat{G}_{1}(t, \mu) e^{\mu x}\right]\right|_{\mu=i n_{1}}=e^{\left(-\frac{1}{2} \alpha^{2} D t+i n_{1} x\right)} \cdot \frac{\sinh \left[i \frac{1}{2} \alpha(l-t) n_{1}\right]}{\sinh \left[i \frac{\alpha}{2} n_{1} l\right]}=\frac{e^{\left(-\frac{1}{2} \alpha^{2} D t+i n_{1} x\right)}}{\sin \left(\frac{\alpha l}{2} n_{1}\right)} \cdot \sin \left[\frac{\alpha(l-t)}{2} n_{1}\right],} \\
{\left.\left[\widehat{G}_{1}(t, \mu) e^{\mu x}\right]\right|_{\mu=-i n_{1}}=\frac{e^{\left(-\frac{1}{2} \alpha^{2} D t-i n_{1} x\right)}}{\sin \left(\frac{\alpha l}{2} n_{1}\right)} \cdot \sin \left[\frac{\alpha(l-t)}{2} n_{1}\right]} \\
{\left.\left[\widehat{G}_{2}(t, \mu) e^{\mu x}\right]\right|_{\mu=i n_{2}}=\frac{e^{\left[-\frac{1}{2} \alpha^{2} D(t-l)+i n_{2} x\right]}}{\sin \left(\frac{\alpha l}{2} n_{2}\right)} \cdot \sin \left[\frac{\alpha t}{2} n_{2}\right]} \\
{\left.\left[\widehat{G}_{2}(t, \mu) e^{\mu x}\right]\right|_{\mu=-i n_{2}}=\frac{e^{\left[-\frac{1}{2} \alpha^{2} D(t-l)-i n_{2} x\right]}}{\sin \left(\frac{\alpha l}{2} n_{2}\right)} \cdot \sin \left[\frac{\alpha t}{2} n_{2}\right]}
\end{gathered}
$$

Substituting the obtained expressions into formula (8) we write the general solution in a form convenient for analysis:

$$
U(t, x) \approx e^{-\chi t} \cdot\left[A_{1} \cdot \sin \left(n_{1} x\right) \cdot \sin \left(\omega_{1} t+\varphi_{l}\right)+A_{2} \cdot \sin \left(n_{2} x\right) \cdot \sin \left(\omega_{2} t\right)\right]
$$

As before, write down the value of the damping factor $\chi$, oscillation frequency $\omega_{1}$ and $\omega_{2}$, phase $\varphi_{l}$, amplitude of oscillations $A_{1}$ and $A_{2}$ :

The damping coefficient of oscillations depends only on the parameters of the line, as for the problem with constant two-point conditions: $\chi=\alpha^{2} D / 2=2.5 \cdot 10^{7} \mathrm{c}^{-1}$.

The oscillation frequencies are determined by both the line parameters and the two-point conditions of the two-point problem: $\omega_{1}=\alpha n_{1} / 2 ; \omega_{2}=\alpha n_{2} / 2$.

Phase shift $\varphi_{l}$ is determined by both the parameters of the line and the value of the time, in the condition of the two-point problem: $\varphi_{l}=\alpha \ln _{1} / 2$.

The amplitudes of oscillations depend on the constants that define the two-point conditions $c_{1}, c_{2}, n_{1}$, $n_{2}$ and line parameters: $A_{1}=c_{1} / \sin \left(\frac{\alpha l}{2} n_{1}\right)$, $A_{2}=c_{2} e^{\frac{\alpha^{2} D l}{2}} / \sin \left(\frac{\alpha l}{2} n_{2}\right)$. 


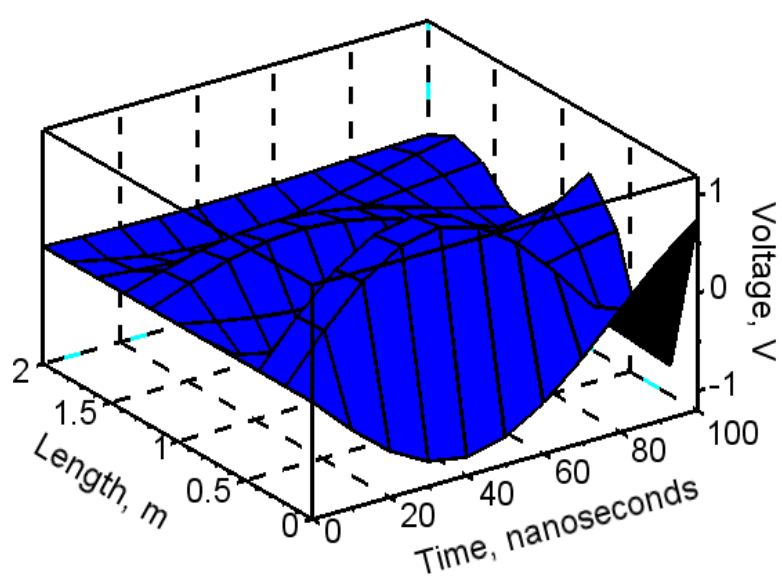

Fig. 4. Spatio-temporal dependence of the amplitude of oscillations in the telegraph line for periodic conditions and constants corresponding to the process of attenuating electromagnetic oscillations with the $\mathrm{x}$-dependent amplitude in the telegraph line (standing wave).

In the previous problem, the value of the time constant was determined $l=10^{-6} \mathrm{~s}=1 \mu \mathrm{s}$. In this case, a large multiplier $e^{25}$ appears in the expression for the amplitude $A_{2}$. Therefore, to determine the conditions of a two-point problem that can be physically realized, we can set the value $c_{2}=0$, which is equivalent to the condition $U(l, x)=\varphi_{2}(x)=0$. Under such conditions, single-frequency damped oscillations are formed:

$U(t, x)=A_{1} \cdot e^{-\chi t} \cdot \sin \left(n_{1} x\right) \cdot \sin \left(\omega_{1} t+\varphi_{1}\right)$

We present the results of numerical simulations for parameter values: $\mathrm{c}_{1}=1 \mathrm{~V} ; \mathrm{n}_{1}=2 ; \mathrm{A}_{1}=-2.14 \mathrm{~V} ; \omega_{1}=$ $\alpha=5 \cdot 10^{8} \mathrm{~Hz} ; \varphi_{l}=500$ radian, or up to the full phase of oscillations: $\varphi_{l}=0.49$ radian.

The spatio-temporal dependence of oscillations in the long line is given in Fig. 4.

Figure 5 shows plots of the voltage distribution along the length of the line in order to demonstrate their dynamics over time.

Thus, in Fig. 5a shows graphs of the stress diagram at the beginning of the oscillating process immediately after the application of voltage to a long line, and in Fig. $5 \mathrm{~b}$ - at the end of the oscillating process (approximately 90 nanoseconds after applying voltage to the line), when the amplitude of oscillations has decreased significantly.

Interestingly, the frequency of these oscillations may not coincide with the frequency of free oscillations of the system. Based on this, it can be concluded that the long line can serve as a device for generating high-frequency oscillations that may exceed the natural frequency of the system. To do this, you need to set the initial voltage distribution in the line, which is described by the harmonic sinusoidal function (Fig. 5a).

\section{Discussion of results and conclusions}

Another aspect of applying the differential-symbol method for a two-point problem is the ability to control the flow of processes in a long line. Measuring the values of the process only at two arbitrary time points allows you to get a complete picture of the value of voltage or current in the line. This leaves open the question of approximating a discrete set of measured values by an analytical function in order to obtain an accurate solution.

The use of two-point conditions can be an effective method of monitoring the state of a long line, because measuring the values of the amplitude of oscillations of physical quantities in the line can give a complete picture of the whole physical process. In particular, this method allows you to predict unwanted increases in amplitude, which can cause damage to the device.

Circles with distributed parameters play an important

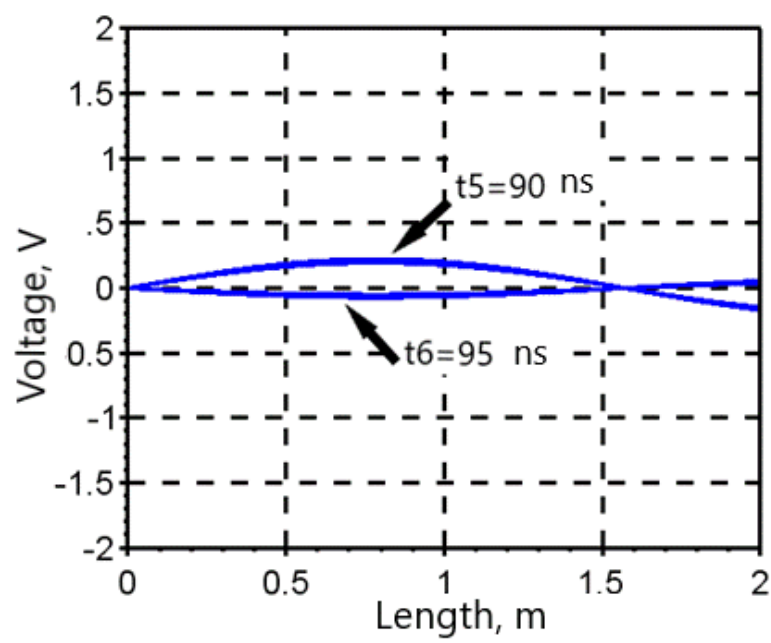

b)

Fig. 5. Voltage distribution along the line: a) at the beginning of the process (maximum oscillation amplitude), b) at the end of the process (reduced oscillation amplitude). 
role in the development of the high-frequency range of electromagnetic oscillations. In particular, such circuits can transmit high-frequency energy (open two-wire lines and coaxial cables). On ultra-wideband spectrum, segments of such lines can be used as bandpass filters or resonators. They can be used to measure wavelength, amplitude of oscillations, resistive and reactive resistances.
Politanskyi R.L. - Dr.Sci., Professor; Nytrebych Z.M. - Dr.Sci., Professor, Head of the Department of Higher Mathematics;

Petryshyn R.I. - Dr.Sci., Professor, Rector;

Kogut I.T. - Dr.Sci., Professor, Head of the Department of Computer Engineering and Electronics;

Malanchuk O.M. - Ph.D., Associate Professor; Vistak M.V. - Dr.Sci., Professor.

[1] R. Politanskyi, M. Klymash, 2019 3rd International Conference on Advanced Information and Communications (Lviv, 2019), p. 390 (https://doi.org/10.1109/AIACT.2019.8847908).

[2] Y. Bobalo, L. Nedostup, M. Kiselychnyk, M. Melen, Computational Problems of Electrical Engineering (CPEE), 17th International Conference (2016), p.1 (https://doi.org/10.1109/CPEE.2016.7738753).

[3] S.D. Galiuk, M.Y. Kushnir, R.L. Politanskyi, 21st International Crimean Conference^ Microwave and Telecommunication Technology (2011), p. 423.

[4] A. Veryga, R. Politanskyi, V. Lesinskyi, T. Ruda, 15th International Conference on Advanced Trends in Radioelectronics, Telecommunication and Computer Engineering (Lviv-Slavske, 2020), p. 162 (DOI: 10.1109/TCSET49122.2020.235414).

[5] Y. Bobalo, M. Kiselychnyk, L. Nedostup, Przegląd Elektrotechniczny 86, 124 (2010).

[6] Z. Mykytyuk, G. Barylo, V. Virt, M. Vistak, I. Diskovskyi, Y. Rudyak, International Scientific-Practical Conference on Problems of Infocommunications, Science and Technology (Kiyv, 2018), p. 177 (https://doi.org/10.1109/INFOCOMMST.2018.8632115).

[7] O. Sushynskyi, M. Vistak, V. Dmytrah, 13th International Conference on Modern Problems of Radio Engineering, Telecommunications and Computer Science (Lviv-Slavske, 2016), p. 418 (https://doi.org/10.1109/TCSET.2016.7452075).

[8] Z. Hotra, Z. Mykytyuk, I. Diskovskyi, G. Barylo, F. Vezyr, 14th International Conference on Advanced Trend in Radioelectronics, Telecommunications and Computer Engineering (Lviv-Slavske, 2018), p. 716 (https://doi.org/10.1109/TCSET.2018.8336300).

[9] R.L. Politanskyi, M.V. Vistak, G.I. Barylo, A.S. Andrushchak, Optical Materials 102, 109782 (2020) (https://doi.org/10.1016/j.optmat.2020.109782).

[10] I.T. Kogut, V.I. Holota, A.A. Druzhinin, V.V. Dovhij, Journal of Nano Research 39, 228 (2016) (https://doi.org/10.4028/www.scientific.net/JNanoR.39.228).

[11] K. Narahara, Journal of Applied Physics 100(6), 064908 (2006).

K. Narahara, T. Yamaki, T. Takahashi, T. Nakamichi, International Journal of High Speed Electronics and Systems 17(3), 577 (2007).

[12] H. Shanak, O. Florea, N. Alshaikh, J. Asad. Acta Technica Napocensis, Ser.: Applied Mathematics and Engineering 63, 143 (2020).

[13] M. Dehghan, A. Ghesmati, Eng. Anal. Boundary Elem. 34(1), 51 (2010).

[14] M. Dehghan, A. Shokri, Numer. Methods Partial Differ. Equ. 24, 1080 (2008) (https://doi.org/10.1002/num.20306).

[15] A. Ashyralyev, M. Modanli, Boundary Value Problems 41, 1 (2015) (https://doi.org/10.1186/s13661-0150302-z).

[16] Z. Nytrebych, O. Malanchuk, Italian J. of Pure and Appl. Mathematics 41, 242 (2019).

[17] Z. Nytrebych, O. Malanchuk, J. Math. Sci. 227, 68 (2017).

[18] Z. Nytrebych, O. Malanchuk, Demonstratio Mathematica 52(1), 88 (2019) (https:// doi.org/10.1515/dema2019-0010).

[19] Z. Nytrebych, O. Malanchuk, Asian-European Journal of Mathematics 12(3), 1950037 (2019) (https://doi.org/10.1142/S1793557119500372). 


\section{Р.Л. Політанський ${ }^{1}$, 3.М. Нитребич ${ }^{2}$, Р.І. Петришин ${ }^{1}$, I.Т. Когут ${ }^{3}$, О. М. Маланчук ${ }^{4}$,} М.В. Вісьтак ${ }^{4}$

\section{Моделювання поширення електромагнітних коливань методом модифікованого рівняння телеграфної лінії}

\footnotetext{
${ }^{1}$ Чернівецький національний університет імені Юрія Федьковича, м. Чернівиі, Україна, r.politansky@chnи.edu.иа

${ }^{2}$ Національний університет «Львівська політехніка», м. Львів, Украйна, znytrebych@ gmail.com

${ }^{3}$ Прикарпатський національний університет імені Василя Стефаника, м. Івано-Франківськ, Україна, igorkohut2202@gmail.com
}

${ }^{4}$ Львівський національний медичний університет імені Данила Галииького, Україна, м. Львів, оksana.malan@gmail.com

У роботі розглянуто фізичні процеси, що пов'язані з поширенням електромагнітних коливань у довгій лінії, розміри якої є співрозмірними або перевищують довжину електромагнітної хвилі. В якості методу дослідження було використано диференціально-символьний метод, який був застосований до модифікованого рівняння телеграфної лінії. Параметрами керування процесом поширення електромагнітних коливань $\epsilon$ граничні умови для двоточкової задачі, а також додаткові параметри, що $\epsilon$ коефіцієнтами при перших похідних за координатою і часом у порівнянні із класичним рівнянням телеграфної лінії. На основі диференціально-символьного методу було знайдено граничні умови двоточкової задачі, при яких у довгій лінії реалізовані найбільш характерні коливні процеси. На основі проведених досліджень можна зробити висновки про ефективність застосування аналітичних методів для аналізу конкретних технічних об’єктів та керування процесами, які у них відбуваються.

Ключові слова. телеграфна лінія, двоточкова задача. 